\title{
Contribution to the study of neotropical discomycetes: a new species of the genus Geodina (Geodina salmonicolor sp. nov.) from the Dominican Republic
}

\author{
Angelini $\mathbf{C}^{1,2}$, Medardi $\mathbf{G}^{3}$, Alvarado $\mathbf{P}^{4}$ \\ ${ }^{1}$ Jardín Botánico Nacional Dr. Rafael Ma. Moscoso, Santo Domingo, República Dominicana \\ ${ }^{2}$ Via Cappuccini 78/8, 33170 (Pordenone) \\ ${ }^{3}$ Via Giuseppe Mazzini 21, I-25086 Rezzato (Brescia) \\ ${ }^{4}$ ALVALAB, La Rochela 47, E-39012 Santander, Spain
}

Angelini C, Medardi G, Alvarado P 2018 - Contribution to the study of neotropical discomycetes: a new species of the genus Geodina (Geodina salmonicolor sp. nov.) from the Dominican Republic. Mycosphere 9(2), 169-177, Doi 10.5943/mycosphere/9/2/1

\begin{abstract}
Geodina salmonicolor sp. nov., a new neotropical / equatorial discomycetes of the genus Geodina, is here described and illustrated. The discovery of this new entity allowed us to propose another species of Geodina, until now a monospecific genus, and produce the first 28S rDNA genetic data, which supports this species is related to genus Wynnea in the Sarcoscyphaceae.
\end{abstract}

Key-words - 1 new species - Ascomycota - Sarcoscyphaceae - Sub-tropical zone Caribbeans Taxonomy

\section{Introduction}

A study started more than 10 years ago in the area of Santo Domingo (Dominican Republic) by one of the authors allowed us to identify several interesting fungal species, both Basidiomycota and Ascomycota. Angelini \& Medardi (2012) published a first report of ascomycetes in which 12 lignicolous species including discomycetes and pyrenomycetes were described and illustrated in detail, also delineating the physical and botanical characteristics of the research area.

During one of the forays in Santo Domingo, another unusual discomycetes in the shape of a small upturned bell was found, characterized by a faint pink to salmon-colored hymenium contrasting with the brownish external surface. A closer examination suggested that it was a species related to the genus Geodina Denison, but different from the only species so far described, $G$. guanacastensis Denison. The first collection consisted of only one apothecium found on a jar of the Jardín Botánico Nacional Dr. Rafael Ma. Moscoso of Santo Domingo. A few years later, a single isolated apothecium of the fungus was found again in two other different places.

We tried to study also the holotypus of G. guanacastensis located in CUP, in order to compare it with our findings and to have more familiarity with the phylogenetic position of the genus, but it was impossible because the Herbarium did not consider our request of loan.

\section{Material \& Methods}

Fungal specimens were photographed in situ, using a digital camera Nikon Coolpix 8400, and then dried using an air dryer. Microscopic examinations and drawings from them were done 
employing dried specimens rehydrated in water, using an Optika optical microscope (BK 1301 model). Mounts were made in water. Melzer's reagent, floxin and cotton blue in lactic acid were used to highlight the spore ornamentation. The herbarium specimens selected for DNA extraction are listed in Table 1. Specimens collected in this study were deposited in JBSD herbarium (Jardín Botánico Nacional Dr. Rafael M. Moscoso, Dominican Republic).

Total DNA was extracted from dried specimens following a modified CTAB-based procedure (Murray \& Thompson 1980). PCR amplifications were performed with the primers ITS1F-ITS4, ITS1F-ITS2, or ITS3-ITS4 (White et al. 1990, Gardes \& Bruns 1993) to amplify the ITS1 and ITS2 rDNA regions, while LR0R and LR5 (Vilgalys \& Hester 1990, Cubeta et al. 1991) were used to amplify the $28 \mathrm{~S}$ rDNA region. Amplification protocol consisted in: $95^{\circ} \mathrm{C}$ initiation for $5 \mathrm{~min} ; 35$ cycles at $95^{\circ} \mathrm{C}$ for $45 \mathrm{~s}, 54^{\circ} \mathrm{C}$ for $30 \mathrm{~s}$, and $72^{\circ} \mathrm{C}$ for $45 \mathrm{~s}$; and a final step at $72^{\circ} \mathrm{C}$ for $10 \mathrm{~min}$. PCR products were checked in $1 \%$ agarose gel prior to purification and sequencing with one or more PCR primers. Chromatograms were visually checked in MEGA5 (Tamura et al. 2011) to detect and fix ambiguous nucleotides and sequencing problems. Consensus sequences were submitted to GenBank (Table 1). Newly generated 28S rDNA sequences and their closest relatives in public databases (coming mainly from Pfister et al. 2008, Romero et al. 2012, Carbone et al. 2013, Hansen et al. 2013), were aligned in MEGA 5.0 software with its Clustal W application and then corrected manually. The final alignment of 28S rDNA sequences (including 304/762 variable sites) was loaded in PAUP* 4.0b10 (Swofford 2001) and subjected to MrModeltest 2.3 (Nylander 2004). Model GTR $+\mathrm{I}+\mathrm{G}$ was selected and implemented in MrBayes 3.1 (Ronquist \& Huelsenbeck 2003), where a Bayesian analysis was performed (two simultaneous runs, six chains, temperature set to 0.2 , sampling every 100th generation) until convergence parameters were met after about $2.21 \mathrm{M}$ generations, standard deviation having fell below 0.01. Finally, a full search for the best-scoring maximum likelihood tree was performed in RAxML (Stamatakis 2006) using the standard search algorithm (2000 bootstrap replications). Significance threshold was set above 0.95 for posterior probability (PP) and 70\% bootstrap proportions (BP).

Table $128 \mathrm{~S}$ rDNA sequences used in the phylogenetic analyses.

\begin{tabular}{|c|c|c|c|c|c|}
\hline Species & $28 S$ rDNA & Species & $28 S$ rDNA & Species & $28 S$ rDNA \\
\hline Chorioactis geaster & KC012672 & Phillipsia carnicolor & JQ260812 & Sarcoscypha austriaca & AY945856 \\
\hline Cookeina insititia & AY945861 & Phillipsia crispata & JQ260813 & Sarcoscypha austriaca & AY945855 \\
\hline Cookeina sp. & KY090805 & Phillipsia domingensis & AY945844 & Sarcoscypha coccinea & FJ176859 \\
\hline Cookeina sp. & KY090983 & Phillipsia domingensis & JQ260817 & Sarcoscypha coccinea & AY544647 \\
\hline Cookeina speciosa & AY945862 & Phillipsia lutea & JQ260816 & Sarcoscypha occidentalis & AY945846 \\
\hline Cookeina tricholoma & AY945860 & Phillipsia olivacea & JQ260814 & Sarcoscypha sp. & KC012700 \\
\hline Donadinia helvelloides & NG_042731 & Phillipsia olivacea & JQ260815 & Sarcosoma globosum & KC109215 \\
\hline Galiella rufa & FJ238401 & Phillipsia sp. & KY498592 & Sarcosoma latahense & FJ176860 \\
\hline Geodina salmonicolor & MG597288 & Phillipsia sp. & KY498590 & Scutellinia scutellata & DQ247806 \\
\hline Geodina salmonicolor & MG597287 & Phillipsia subpurpurea & KY498591 & Trichaleurina celebica & KF418258 \\
\hline Kompsoscypha phyllogena & JQ260810 & Pithya cupressina & JQ260818 & Trichaleurina javanica & JX669861 \\
\hline Microstoma floccosum & JN012013 & Plectania melastoma & JX669850 & Urnula craterium & AY945851 \\
\hline Microstoma floccosum & DQ220370 & Pseudopithyella minuscula & AY544658 & Wolfina aurantiopsis & AY945859 \\
\hline Nanoscypha tetraspora & DQ220374 & Pseudoplectania nigrella & NG_042728 & Wynnea americana & AY945848 \\
\hline Phillipsia carnicolor & JQ260811 & Rickiella edulis & JQ260809 & Wynnea sparassoides & EU360917 \\
\hline
\end{tabular}




\section{Results}

Analysis of 28S rDNA suggested that the samples collected are significantly related to genus Wynnea Berk. \& M.A. Curtis and subfamily Wynneae of the Sarcoscyphaceae Le Gal ex Eckblad (Fig. 1). A significant support for subfamily Boedijnopezizeae was also obtained, but not for Sarcoscypheae Fr., in contrast with previous authors (Romero et al. 2012). No intraspecific variability of $28 \mathrm{~S}$ or ITS rDNA sequences was observed between the samples analyzed, suggesting that they belong to a single taxon, which is here proposed as new species of Geodina because of the morphological similarity (but not identity) with the type species of this genus, G. guanacastensis.

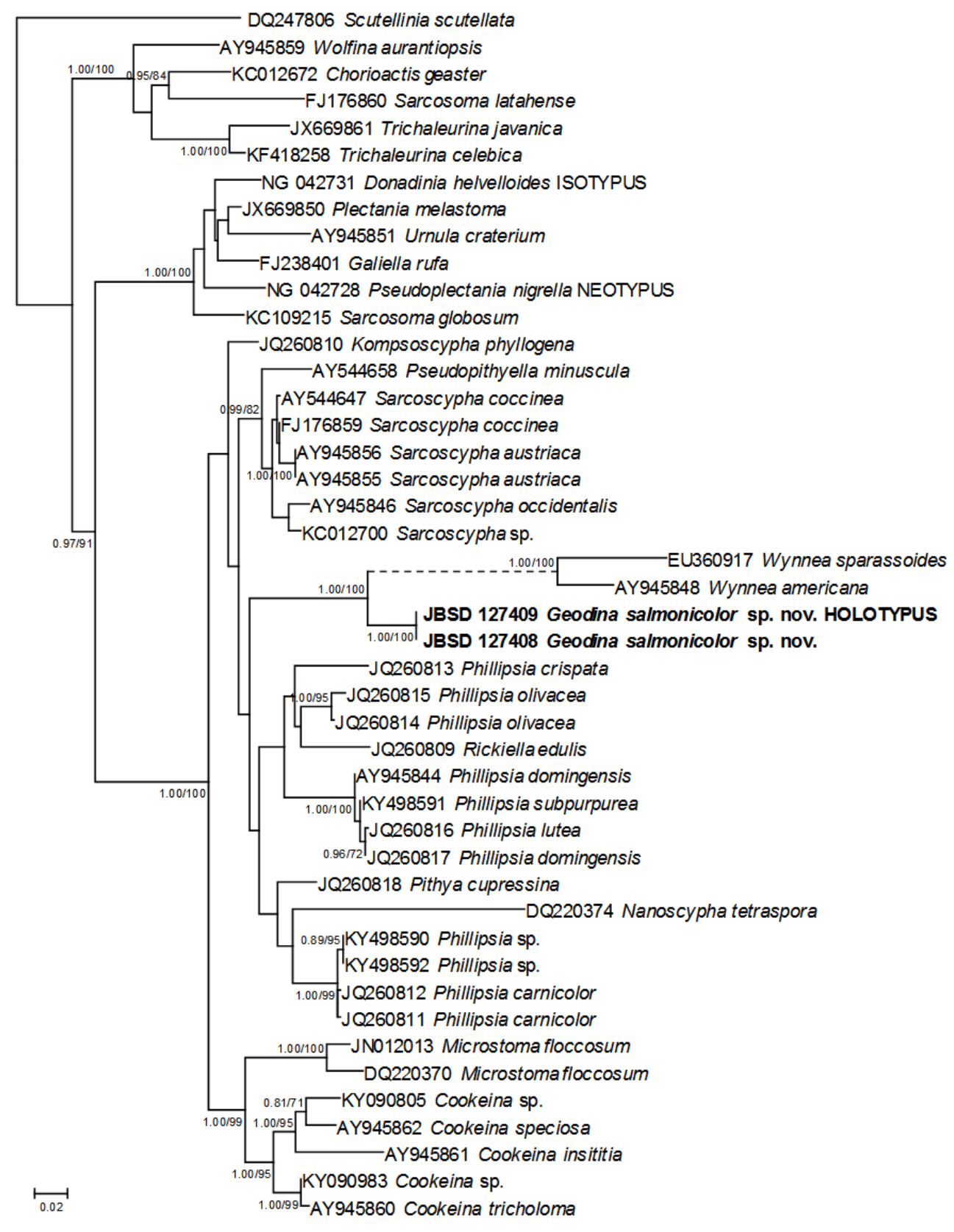

Figure $1-50 \%$ majority rule consensus 28S rDNA phylogram of the family Sarcoscyphaceae obtained in MrBayes from 16575 sampled trees. Nodes supported by $>0.95$ Bayesian PP or $>70 \%$ ML BP are shown annotated. Sequences obtained in the present study are shown in bold characters.

Geodina salmonicolor Angelini \& Medardi, sp. nov.

Figs 2-4 


\section{MycoBank: MB823851}

Etymology - for the hymenial color, delicately rosy-orange or pale pink-orange.

\section{Diagnosis}

Fruitbody funnel-shaped, up to $40 \mathrm{~mm}$ height and 25-30 mm diam. Apothecium cup-shaped to urceolate. Hymenial surface smooth, faint pink salmon to pale pink-orange. Receptacle surface pale chocolate-brown, pale brown-greyish, with dark brown hairs, zoned by some rings alternately pale and dark, more conspicuous near the margin. Margin entire or shortly cracked. Stalk up to 25 mm long, tapered and curved, smooth, dark brown. Flesh waxy but elastic, whitish or slightly pink in the cup, brownish and fibrous in the stalk.

Ascospores 35-39 × 14-15 $\mu$ m, ellipsoid or citriform, smooth and oil-dropped when young, hyaline, after that developing ornaments consisting of coarse, more or less irregularly arranged ridges ribs up to $2 \mu \mathrm{m}$ broad and high, curved, often anastomosed to form portions of a partial reticulum. Asci 300-380 (450) × 18-21 $\mu \mathrm{m}, 8$-spored, with long, curved and gradually tapered base, unamyloid, sub-operculates. Paraphyses cylindrical at the base $(2-3 \mu \mathrm{m})$, broadening up to 5 $\mu m$ at the top and near the septa, scarcely anastomosed only in the lower part. Subhymenium not observed. Medullar excipulum up to $600 \mu \mathrm{m}$ thick; textura intricata, hyphae 2.5-3 $\mathrm{mm}$, interwoven, branched, septate, hyaline. Ectal excipulum 350-400 $\mu \mathrm{m}$ thick; textura globulosa or globulosaangularis, cells up to $25 \mu \mathrm{m}$ diam., $25 \times 10 \mu \mathrm{m}$ or $20 \times 15 \mu \mathrm{m}$ if compressed, dark brown to blackish-brown. Hairs 500-550 $\mu \mathrm{m}$ long, 10-15 $\mu \mathrm{m}$ large at the top and 20-40 $\mu \mathrm{m}$ at the base, made up of fasciculate, cylindrical, closed hyphae 4-4.5 $\mu \mathrm{m}$, with a few septa, dark brown.

Holotypus hic designatus: Dominican Republic, Santo Domingo, on humous soil and litter in the natural part of the Jardín Botánico Nacional dr. Rafael Ma. Moscoso, under tropical mixed indigenous hardwood trees, 08 Nov 2011; leg. C. Angelini, det. C. Angelini \& G. Medardi (JBSD127409, GenBank acc. n. MG597290, MG597288).

\section{Extended description}

Fruitbody funnel-shaped, up to $40 \mathrm{~mm}$ high and 25-30 $\mathrm{mm}$ diam. Apothecium like an overturned bell, strongly cup-shaped (up to $20 \mathrm{~mm}$ deep). Hymenial surface smooth, delicate pink salmon to pale pink-orange. Receptacle surface more or less pale chocolate-brown, tobacco with greyish reflexes, with clearly visible dark brown hairs up to the edge; some pale and dark concentric rings can be seen, especially near the margin. Margin entire or shortly cracked, undulated, slightly lobed, at times somewhat reflexed. Stalk up to $25 \mathrm{~mm}$ long, cylindrical, often curved, tapered toward the bottom (1-2 mm diam.) and wider at the top where it reaches the cup, 1.5-4.5 mm diam., smooth, dark brown, darker at the base; some longitudinal furrows and/or small cavities can be present near the junction of the stalk with the apothecium. Flesh waxy but not brittle, rather elastic, whitish or faintly pink in the apothecium, brownish and more fibrous in the stalk.

Ascospores 35-39 $\times 14-15 \mu \mathrm{m}$, elliptical or citriform, heavily sculptured, thick-walled (up to 2-2.5 $\mu \mathrm{m}$ ), when young smooth and with some oil drops, hyaline, uniseriate in the asci; spore ornaments consisting in coarse, more or less longitudinal, oblique or transversal ridges up to $2 \mu \mathrm{m}$ broad and high, curved, often anastomosed and joined to form portions of irregular or partial reticulum. Asci 300-380 (-450) × 18-21 $\mu \mathrm{m}, 8$-spored, cylindrical, thick-walled (up to $3 \mu \mathrm{m})$, with long, often curved and gradually tapering base, unamyloid, sub-operculates; operculum typically eccentric and quite small $(5-6 \mu \mathrm{m})$, round or elliptical. Paraphyses cylindrical at the base $(2-3 \mu \mathrm{m}$ diam.), clavate and enlarged up to $5 \mu \mathrm{m}$ at the top and near the septa, some of them forked, sometimes anastomosed at the base, without oil-drops. Subhymenium not observed. Medullary excipulum up to $600 \mu \mathrm{m}$ thick; textura intricata, hyphae 2.5-3 $\mu \mathrm{m}$ broad, interwoven, forked, septate, hyaline. Ectal excipulum 350-400 $\mu \mathrm{m}$ thick; textura globulosa or globulosa-angularis, cells up to $25 \mu \mathrm{m}$ diam., globose or compressed (and then of $25 \times 10 \mu \mathrm{m}$ or $20 \times 15 \mu \mathrm{m}$ ), wallthickened $(1-1.5 \mu \mathrm{m})$, more or less dark brown to blackish-brown. Extracellular dark brown pigments present. Hairs 500-550 $\mu \mathrm{m}$ long, 10-15 $\mu \mathrm{m}$ large at the top and 20-40 $\mu \mathrm{m}$ near the base, 
originating from the ectal excipulum, single or clustered, composed of 2-3 or several fasciculate hyphae, more or less parallel and densely packed. Hyphae are 4-4.5 $\mu \mathrm{m}$ broad, cylindrical, with rounded apices, thin-walled $(0.5-1 \mu \mathrm{m})$, with a few septa, dark brown; they are more abundant and shorter at the base, making every single hair of a strictly triangular shape. Some scattered, small scales (approximately up to $90 \times 45 \mu \mathrm{m}$ ) can be found among the hairs, triangular, made up of hyphae similar to those composing the hairs but markedly shorter, septate (maybe hairs still developing).

Habitat - generally solitary on rich soil and litter in deciduous tropical and equatorial woods, November-December. As stated by DENISON (1965: 651) for G. guanacastensis, the fungus grows on soil, but the stalk could reach some buried wood below.
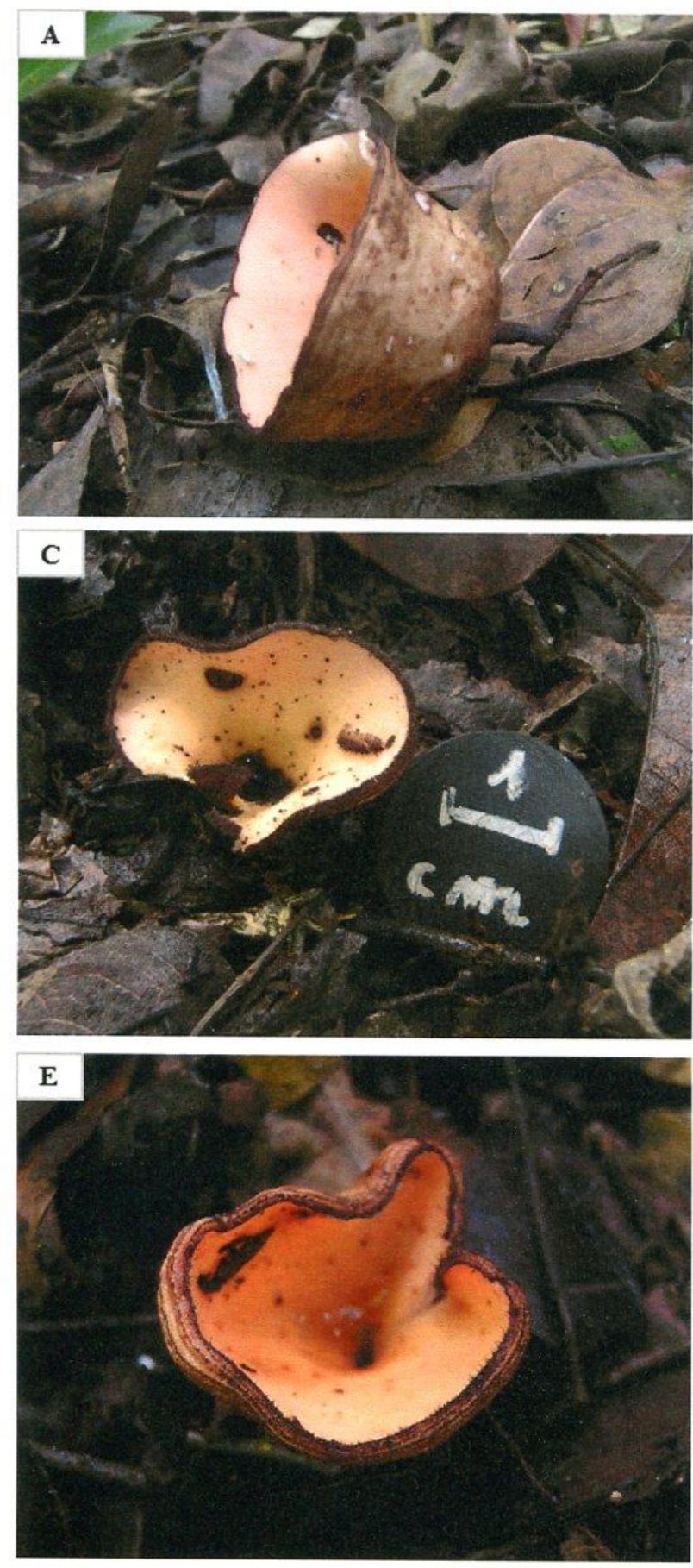
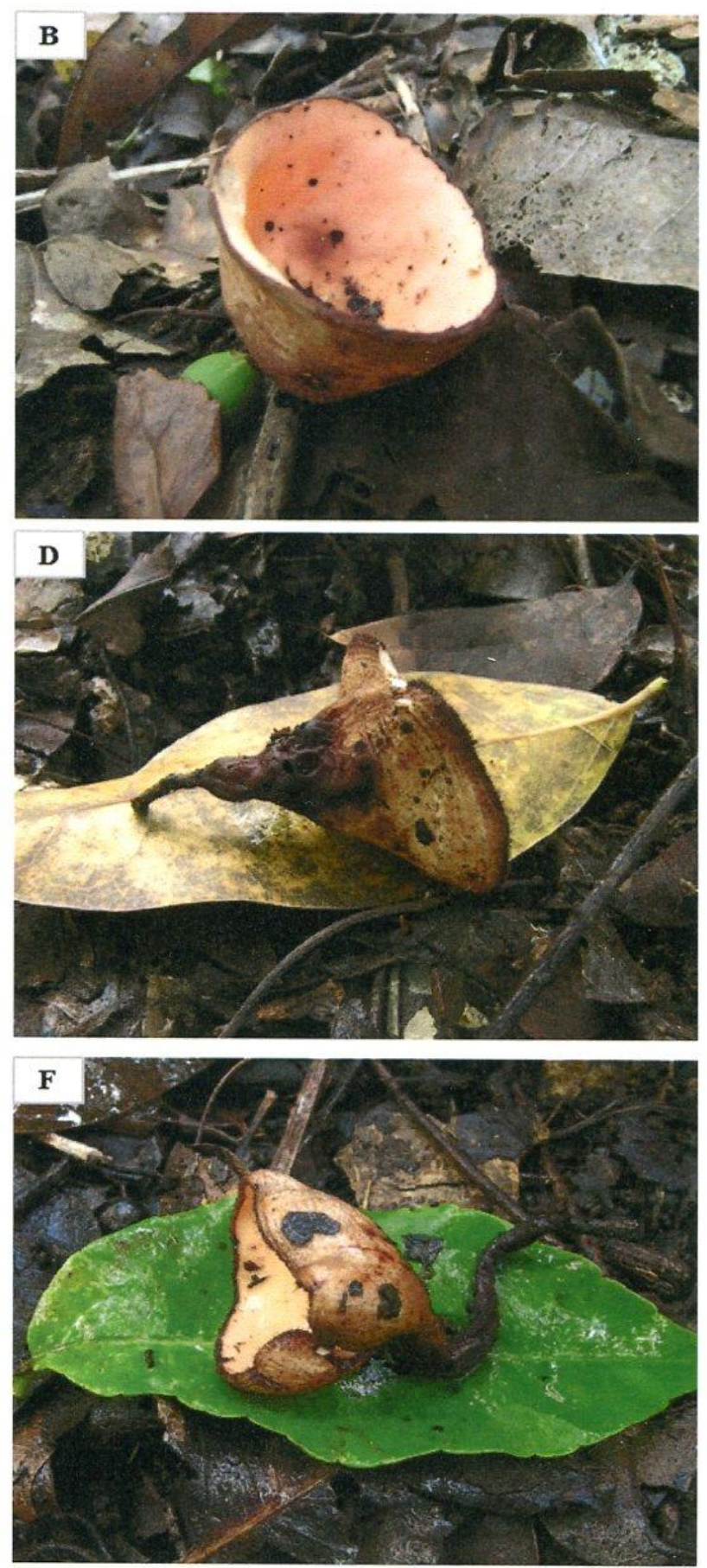

Figure 2 - Geodina salmonicolor. A, B first collection (JBSD 127409, holotypus). C, D second collection (ANGE 759). E, F third collection (JBSD 127408). 

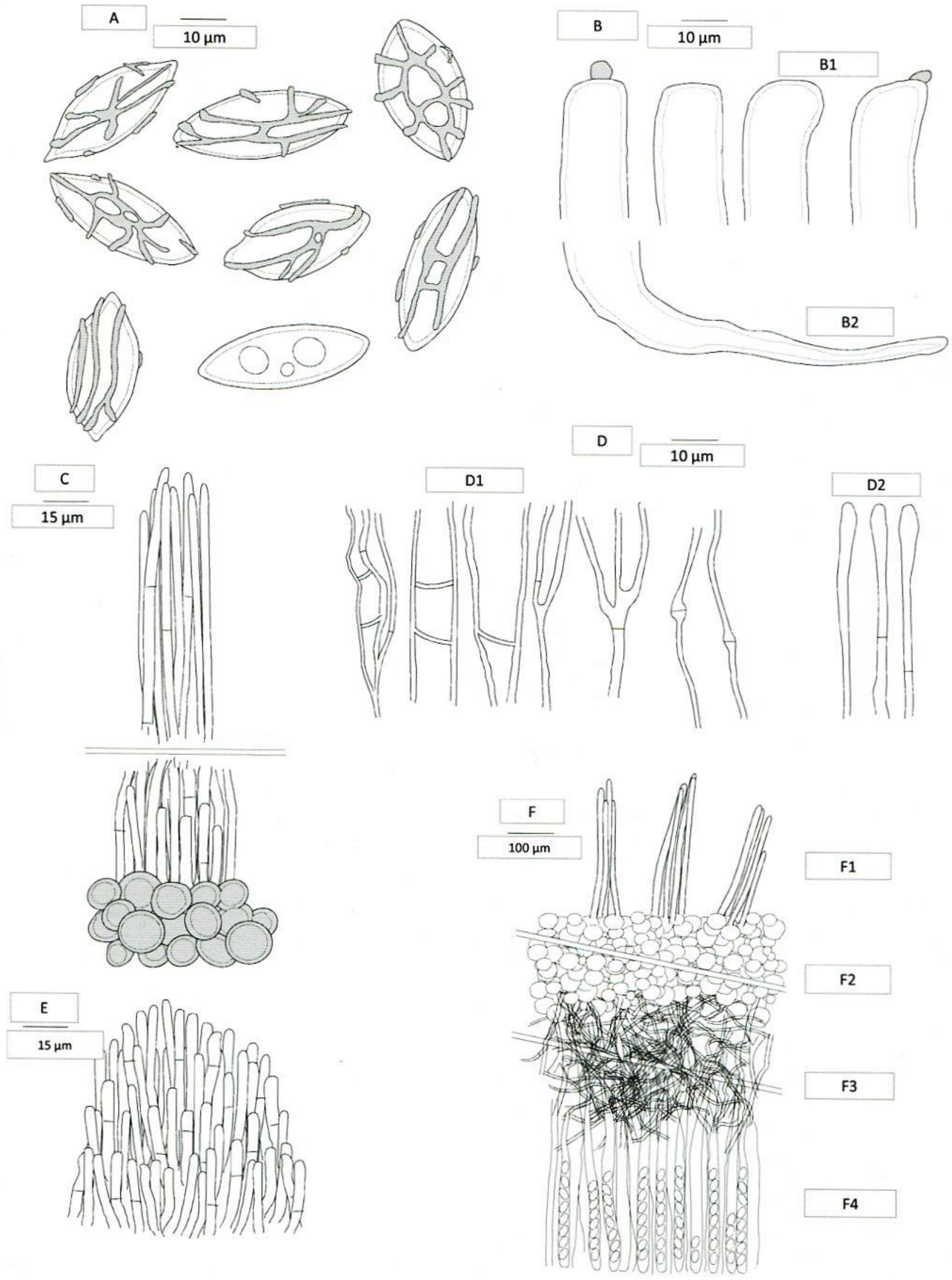

Figure 3 - Geodina salmonicolor. A Released ascospores. B Asci (B1- apex shape. B2 base shape). C Hairs. D Paraphyses (D1 lower part. D2 upper part). E Scales near the hairs base. F Diagrammatic vertical section of one apothecium (F1 Hairs. F2 Ectal excipulum F3. Medullar excipulum. F4 Hymenium). 


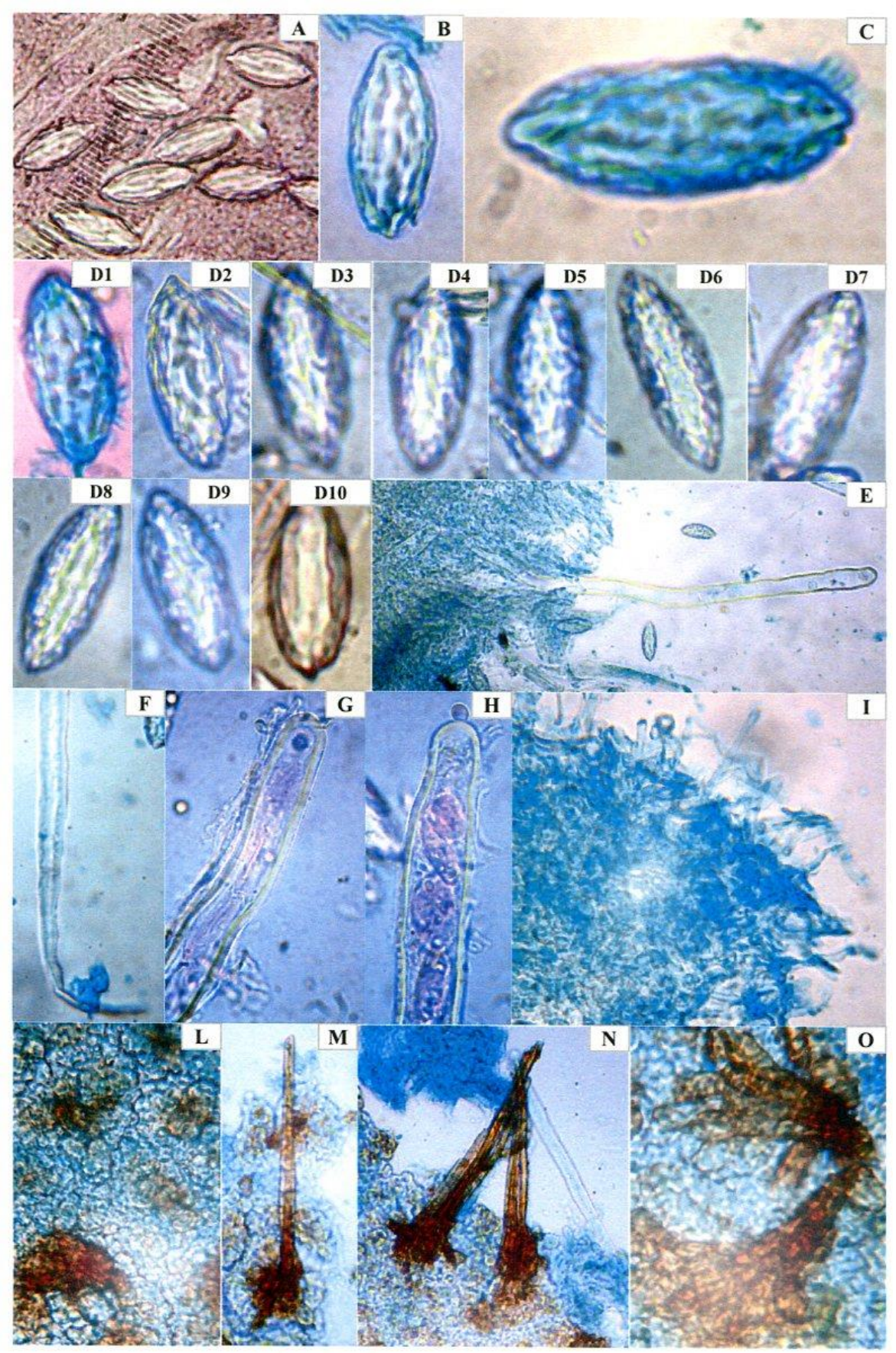

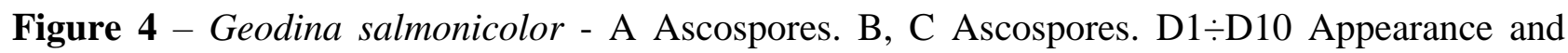
general outline of the spore surface ribs. E Ascus in Lactic blue. F Ascus base. G Ascus top. H Ascus top and operculum. I Medullar excipulum. L Ectal excipulum. M, N hairs. O scales. (A, D2 -D10, G, H - Phloxin; B, C, D1, E, F, I, L, M, N, O - Lactic blue). [Scale bar: - (5 mm): A, G, $\mathrm{H}=20 \mu \mathrm{m} ; \mathrm{B}, \mathrm{D} 1 \div \mathrm{D} 10=10 \mu \mathrm{m} ; \mathrm{C}=6 \mu \mathrm{m} ; \mathrm{E}=50 \mu \mathrm{m} ; \mathrm{F}=25 \mu \mathrm{m} ; \mathrm{I}=100 \mu \mathrm{m} ; \mathrm{L}, \mathrm{M}, \mathrm{N}, \mathrm{O}=80$ $\mu \mathrm{m}]$.

Other specimens examined - 23 Nov 2016, Sosúa (P.to Plata) loc. Cemetery, leg. C. Angelini, det. C. Angelini \& G. Medardi (ANGE759); 25 Dec 2016, Sosúa (P.to Plata) loc. Cemetery, leg. C. Angelini, det. C. Angelini \& G. Medardi (JBSD127408).

\section{Discussion}

The monotypic genus Geodina belongs to the family Sarcoscyphaceae (Wijayawardene et al. 2017, 2018), integrated by stalked species with tough or elastic apothecia, commonly growing on 
logs or wood debris in early stages of decay. Their elastic consistency is due to the textura intricata (prosenchyma) generally present in large amount in the structure of the flesh. Asci of the Sarcoscyphaceae are sub-operculate, markedly thick-walled (mainly at the top) and typically with an eccentric operculum. Eckblad (1968) distinguished two tribes in that family, Sarcoscypheae Fr. and Urnuleae Eckblad, the former based on light colour and presence of carotenoid pigments, the latter with dark tints and lacking of carotenoid. He classified Geodina within Sarcoscyphae because of its morphological features.

Morphologically, Geodina recalls Cookeina Kunze; because of their sub-operculate asci, hairs shape and structure, and the presence of prosenchymatous tissue in the structure of the trama. However, Cookeina has the base of the asci abruptly tapered and ending in a thin, often curved thread-like appendage, the paraphyses are closely anastomosed at all levels by transversal or oblique septa, and the ascospores show only some longitudinal thin lines (Angelini \& Medardi 2012, Dennis 1970, Le Gal 1953, Seaver 1928). According to Denison (1965) there is another important difference between the two genera: all asci mature simultaneously in Cookeina, but in separate groups in Geodina, so that in the same section we can observe asci at different stages of development, with ascospores completely mature or empty.

Denison (1965) created the genus Geodina for the only species known at that time, $G$. guanacastensis, characterized by its stalked apothecia with an hymenial surface pale orange to light yellow-orange and a concolor outer surface looking darker because of a coat of dark brown hairs 300-800 $\mu \mathrm{m}$ long, smaller ascospores 22-25 × 11-13 $\mu \mathrm{m}$, and fruiting on naked soil. Geodina salmonicolor differs because of 1) brownish zoned outer surface, 2) larger spores, 3) presence of some septa in the thin-walled hyphae composing the hairs, 4) shorter hairs mixed with scattered scales, 5) a smaller and more regular operculum than that drawn by Denison (1.c.: 652), 6) oil drops visible only in young ascospores, and 7) ectal excipulum of textura globulosa or globulosaangularis instead of prismatica or angularis.

\section{Short dichotomic key for the species of the genus Geodina}

1 - Ascospores $22-25 \times 11-13 \mu \mathrm{m}$. Hymenial surface pale orange to light yellow-orange; outer surface concolorous. Hairs 300-800 $\mu \mathrm{m}$ long, made up by hyphae without septa

G. guanacastensis

1 - Ascospores 35-39 × 14-15 $\mu \mathrm{m}$. Hymenial surface delicate pink salmon to pale pink-orange; outer surface more or less pale chocolate-brown, tobacco with greyish reflexes, zoned by some rings alternately pale and dark, more closed near the margin. Hairs 500-550 $\mu \mathrm{m}$ long, made up by septate hyphae

G. salmonicolor

\section{Acknowledgments}

We wish to thank F. Jimenez, R. Garcia and A. Veloz (Jardín Botánico Nacional, Dr. Rafael Ma. Moscoso - Santo Domingo, Dominican Republic) for their interest and encouragement to study the fungi of the Dominican Republic and for their active cooperation in putting at our disposal material in the Herbarium of the Botanical Garden of Santo Domingo.

\section{References}

Angelini C, Medardi G. 2012 - Tropical fungi: twelve species of lignicolous Ascomycota from the Dominican Republic. Mycosphere 3 (5), 567-601.

Carbone M, Agnello C, Alvarado P. 2013 - Phylogenetic studies in the family Sarcosomataceae (Ascomycota, Pezizales). Ascomycete.org 5(1), 1-12.

Cubeta MA, Echandi E, Abernethy T, Vilgalys R. 1991 - Characterization of anastomosis groups of binucleate Rhizoctonia species using restriction analysis of an amplified ribosomal RNA gene. Phytopathology 81: 1395-1400. 
Denison WC. 1965 - Central American Pezizales. I. A new genus of the Sarcoscyphaceae. Mycologia 57 (4), 649-656.

Dennis RWG. 1970 - Fungus Flora of Venezuela and adjacent countries. Kew Bulletin, Additional series III. Her Majesty's Stationery Office, London.

Eckblad FE. 1968 - The genera of the Operculate Discomycetes. A revaluation of their taxonomy, phylogeny and nomenclature. Nytt. Mag. Bot. 15, 1-192.

Gardes M, Bruns TD. 1993 - ITS primers with enhanced specificity for Basidiomycetes application to the identification of mycorrhizae and rusts. Molecular Ecology 2, 113-118.

Hansen K, Perry BA, Dranginis AW, Pfister DH. 2013 - A phylogeny of the highly diverse cupfungus family Pyronemataceae (Pezizomycetes, Ascomycota) clarifies relationships and evolution of selected life history traits. Molecular Phylogenetics and Evolution 67(2), 311335.

Le Gal M. 1953 - Les Discomycetes de Madagascar. Paris. Laboratoire de cryptogramie du Muséum national d'histoire naturelle. Prodr. Fl. Mycol. Madag. 4, 1-465.

Murray MG, Thompson WF. 1980 - Rapid isolation of high molecular weight plant DNA. Nucleic Acids Research 8(19):4321-4325.

Nylander JAA. 2004 - MrModeltest 2. Uppsala, Sweden: Evolutionary Biology Centre, Uppsala University, Uppsala.

Pfister DH, Slater C, Hansen K. 2008 - Chorioactidaceae: a new family in the Pezizales (Ascomycota) with four genera. Mycological Research 112(5), 513-527.

Ronquist F, Huelsenbeck JP. 2003 - MrBayes 3: Bayesian phylogenetic inference under mixed models. Bioinformatics 19, 1572-1574.

Romero AI, Robledo G, LoBuglio KF, Pfister DH. 2012 - Rickiella edulis and its phylogenetic relationships within Sarcoscyphaceae. Kurtziana 37(1), 79-89.

Seaver FJ. 1928 - The North American Cup-fungi (Operculates), New York.

Stamatakis A. 2006 - RAxML-VI-HPC: maximum likelihood based phylogenetic analyses with thousands of taxa and mixed models. Bioinformatics 22: 2688-2690.

Swofford DL. 2001 - PAUP*4.0b10: phylogenetic analysis using parsimony (and other methods). Sinauer Associates, Sunderland, Massachusetts.

Tamura K, Peterson D, Peterson N, Stecher G et al. 2011 - MEGA5: molecular evolutionary genetics analysis using maximum likelihood, evolutionary distance, and maximum parsimony methods. Molecular Biology \& Evolution 28, 2731-2739.

Vilgalys R, Hester M. 1990 - Rapid genetic identification and mapping of enzymatically amplified ribosomal DNA from several Cryptococcus species. Journal of Bacteriology 172: 4238-4246.

White TJ, Bruns T, Lee S, Taylor JW. 1990 - Amplification and direct sequencing of fungal ribosomal RNA genes for phylogenetics. 315-322, in: MA Innis et al. (eds). PCR protocols: a guide to methods and applications. Academic Press Inc., New York.

Wijayawardene NN, Hyde KD, Rajeshkumar KC, Hawksworth DL et al. 2017 - Notes for genera: Ascomycota. Fungal Diversity 86: 1-594.

Wijayawardene NN, Hyde KD, Lumbsch HT, Liu JK et al. 2018 - Outline of Ascomycota: 2017. Fungal Diversity 88: 167-263. 